\title{
Clarifying the occurrence and conservation status of Plantago dielsiana Pilg. and P. australis Lam. subsp. pretoana Rahn (Plantaginaceae) in Brazil
}

\author{
Gustavo Hassemer $^{1^{*}}$, Rafael Trevisan ${ }^{2}$ and Nina Rønsted ${ }^{1}$ \\ 1 Københavns Universitet, Statens Naturhistoriske Museum, Sølvgade 83S, 1307 Copenhagen, Denmark \\ 2 Universidade Federal de Santa Catarina, Centro de Ciências Biológicas, Departamento de Botânica, 88040-900 Florianópolis, SC, Brazil \\ * Corresponding author: Email: gustavonaha@gmail.com
}

\begin{abstract}
Problems in the original description of a species can have long-lasting consequences. This is the case of Plantago dielsiana and P. australis subsp. pretoana, two taxa referred to occur in Brazil by different authors. This work has the objective of clarifying the long-standing misunderstanding about the occurrence of these two taxa in Brazil. Additionally, we revise the distribution and assess the conservation status of $P$. australis subsp. pretoana, an endangered, rather poorly understood subspecies endemic to southeastern Brazil.
\end{abstract}

Key words: endemic species, distribution, Plantagineae, South America, taxonomy

Plantago L. is a cosmopolitan genus of approximately 250 species, concentrated in temperate and high elevation tropical regions (Rahn 1996; Rønsted et al. 2002; Hefler et al. 2011; Meudt 2012). Plantago species are anemophilous herbs or rarely subshrubs, perennial or annual (Rønsted et al. 2002; Meudt 2012). A few of these species are adapted to anthropic environments (ruderal species), as a result becoming widely distributed (like $P$. major L. and P. lanceolata L.), but most species have restricted distribution and occur in more specialised environments (Rahn 1996; Mohsenzadeh et al. 2010; Segarra and Wood 2011; Hassemer and Baumann 2014; Hassemer et al. 2014). Some Plantago species are endemic to small oceanic islands (Rahn 1996; Dunbar-Co et al. 2008; Meudt 2012). Because of its complex taxonomy (Ishikawa et al. 2009; Meudt 2011), it is not uncommon to find misidentified herbarium Plantago specimens, or even herbarium collections including specimens of different Plantago species. More drastic, however, is when such problems occur in the original description of a species: this is the case of $P$. dielsiana Pilg. (Pilger 1928).

Depending on the author, either Plantago dielsiana or P. australis Lam. subsp. pretoana Rahn (Rahn 1964) is referred to occur in Brazil (Pilger 1928, 1937; Rahn 1964, 1974; Souza 2010; Kaehler 2014). A thorough literature review reveals a complicated taxonomic situation: in his description of $P$. australis subsp. pretoana, Rahn (1964) elected as holotype one of the paratypes of $P$. dielsiana [A.F.M. Glaziou 8897, C]. This taxonomic incident is here shown to be the cause of a long-standing misunderstanding about these two taxa.

To clarify the taxonomic situation and the distribution of these two taxa we revised the entire Plantago collections at herbaria C, EFC, FLOR, HBR, ICN, MBM and UPCB, and loan collections from RB. Additionally, we examined high-resolution images of collections from herbaria $G, K, R, S$ and US.

The revision of the materials from $\mathrm{RB}$ (nine collections originating from Serra do Itatiaia, southeastern Brazil, all previously identified as Plantago dielsiana) showed that these belong to P. australis subsp. pretoana. We thus agree with Rahn $(1964,1974)$, in that the two collections from Serra do Itatiaia [P.K.H. Dusén 587 and A.F.M. Glaziou 8897] cited in the original description of Plantago dielsiana by Pilger (1928) belong to P. australis subsp. pretoana, and that only the type [J.E. Gibert 968] from Montevideo, Uruguay, belongs to P. dielsiana. The main morphological differences between these two taxa are presented in Table 1. Based on literature review (Pilger 1928, 1937; Rahn 1964, 1974, 1983, 1995; Souza 2010; Hefler et al. 2011; Hassemer and Baumann 2014; Hassemer et al. 2014) we recognise 17 species and subspecies of Plantago in Brazil (Table 2).

Plantago dielsiana (Figure 1) is a rather rare species, endemic to Pampean grasslands, restricted to southern Uruguay and eastern Buenos Aires province, eastern Argentina, at elevations no higher than $300 \mathrm{~m}$ above sea level (a.s.l.) (Rahn 1974, 1995). It does not occur in Brazil, and therefore should be removed from the "List 
Table 1. Main morphological differences between Plantago australis subsp. pretoana and P. dielsiana.

\begin{tabular}{lll}
\hline & P. australis subsp. pretoana & P. dielsiana \\
\hline Leaves & Rather thin; margin with inconspicuous teeth & Rather thick; margin with prominent teeth \\
Roots & No taproot; many cord-like roots & A thickened taproot, to $17 \mathrm{~cm}$ long \\
Caudex & A rhizome, $1-10 \mathrm{~cm}$ or longer & Rather inconspicuous, to $1 \mathrm{~cm}$ long \\
Bracts & Glabrescent & Ciliate \\
Ovary & 2 ovules & 1 ovule \\
\hline
\end{tabular}

of Species of the Flora of Brazil" (Souza and Hassemer 2015).

Plantago australis subsp. pretoana (Figure 2) is a much rarer subspecies, exclusive to two small, considerable distinct areas: high elevation rocky bogs in the highest areas of Serra do Itatiaia, southeastern Brazil, at 2,000-2,600 $\mathrm{m}$ a.s.l., and wet grasslands around Lagoa Dourada, in Ponta Grossa, Paraná state, southern Brazil, at $790-840 \mathrm{~m}$ a.s.l. With the examination of the collections cited by Rahn (1974) for the southern Brazilian states of Santa Catarina [L.B. Smith et al. 7712, HBR; see Figure 36 in Rahn 1974] and Rio Grande do Sul [B. Rambo 51492, HBR] we realised that these collections are certainly not of $P$. australis subsp. pretoana. These doubtful collections are being further investigated. The only two collections of this subspecies from Lagoa Dourada are from 1914 [G. Jönsson 116oa, G, S, US] and 1978 [L.T. Dombrowski 9695, MBM], and since then it was not collected there again, despite great collection efforts in the area, including fieldwork conducted there by GH in January 2015. Therefore, it is possible that this subspecies may be locally extinct in Paraná. The conservation

Table 2. List of accepted Plantago species and subspecies in Brazil. Subgenera and sections follow Rahn (1996), updated by Rønsted et al. (2002). Non-native species are marked with an asterisk.

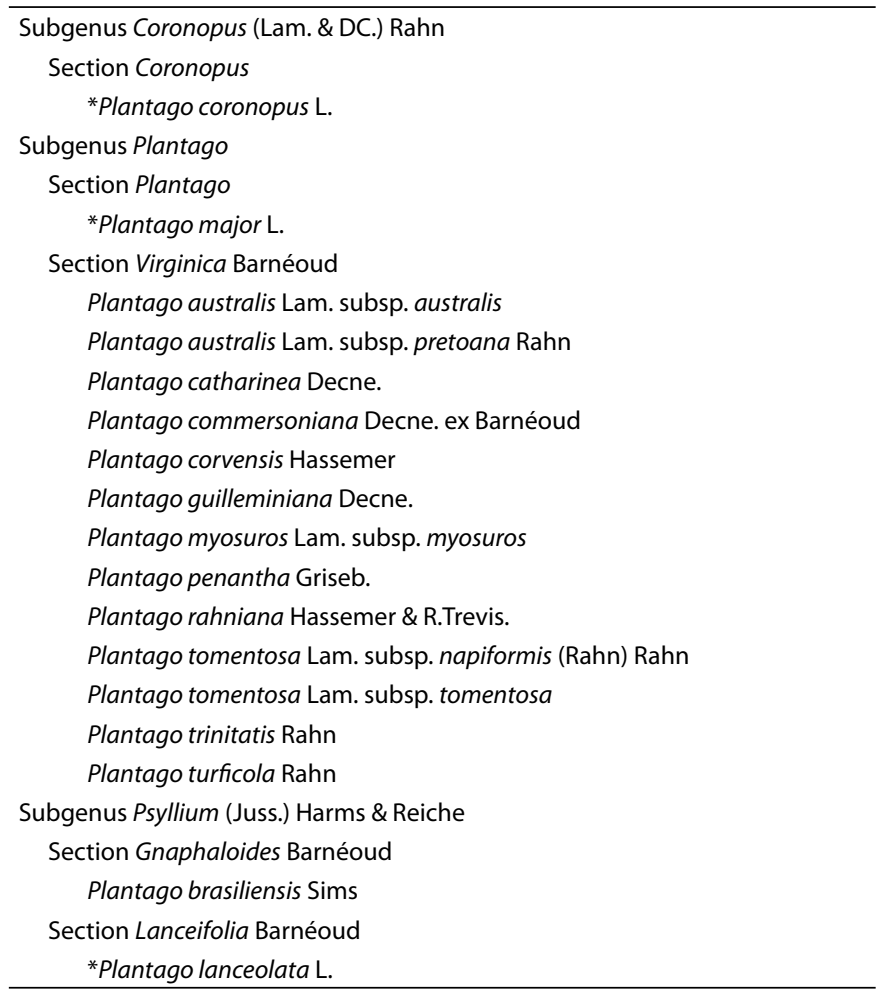

status of $P$. australis subsp. pretoana, according to the IUCN criteria (IUCN 2012, 2014), is here assessed as Endangered (EN-B2a,b[iii]). It is necessary its inclusion in the "Red Book of the Flora of Brazil" (Martinelli and Moraes 2013).

\section{MATERIAL EXAMINED:}

Plantago australis subsp. pretoana. BRAzIL. Minas Gerais: Bocaina de Minas: Itatiaia, an Tijuca près de la source du Rio Preto, 20 November 1876, A.F.M. Glaziou 8897 (C, holotype, R). Paraná: Ponta Grossa: 23. Turma, locis uliginosis et humidis, 19 October 1914, G. Jönsson 116oa (G, S, US); Lagoa Dourada, campo, 17 August 1978, L.T. Dombrowski 9695 (MBM). Rio de Janeiro: Itatiaia: Serra do Itatiaia, in campis humidis, 15 June 1902, P.K.H. Dusén 587 (R); Serra da Mantiqueira, 2,300 m, 3 March 1931, R.W. Kaempfe 417 (RB); Primeiro córrego, 28 December 1934, R.K.F. Pilger 72 (RB); Pântanos no planalto, 2,300-2,400 m, 28 December 1934, R.K.F. Pilger \& A.C. Brade 105 (FLOR, RB); Ribeirão das Flores, 2,200 m, November 1938, F. Markgraf \& A.C. Brade 3725 (FLOR, RB); Planalto, km 20, 12 October 1945, A.B. Pereira \& Walter 107 (FLOR, RB); Planalto, lugar úmido, 2,300 m, 1 March 1950, A.C. Brade 20241 (FLOR, RB); Prateleiras, 4 June 1975, A.M. Camerik 100 (RB); Prateleiras, 25 June 1975, A.M. Camerik 195 (RB); Parque Nacional do Itatiaia, estrada para o Pico das Agulhas Negras, paredões úmidos, 13 March 2010, J.M. Silva \& J. Cordeiro 7554 (MBM); s.d., A.C. Brade s.n. (RB 62313).

Plantago dielsiana. ArgentinA. Buenos Aires: Balcarce: Estancia El Volcán, en potrero de "Trebol Frutilla", 27 January 1960, E. Nicora 6918 (C); Road from Mar del Plata to Balcarce, Puerta del Abra, between $\mathrm{km} 45$ and 46 , east side of the road, in short grass and in open ground by roadside fence, sandy soil, $37^{\circ} 53^{\prime} \mathrm{S}, 05^{\circ} \mathrm{O} 3^{\prime} \mathrm{W}$, 3 April 1966, J.G. Hawkes et al. 4038 (C); Mar Chiquita: Arroyo Los Cueros, N. of Cobo, by bridge (Ruta 2), in overtrodden places, $37^{\circ} 46^{\prime} \mathrm{S}$, $057^{\circ} 38^{\prime} \mathrm{W}, 26 \mathrm{~m}, 12$ December 1965, J.G. Hawkes et al. 3030 (C); Mar del Plata: Plaza Gral. Pueyredon, 15 December 1964, Okada 2092 (C). URUGUAY. Canelones: Arenares de Carrasco, January 1936, A. Lombardo 4785 (C). Montevideo: in uliginosis, s.d., J.E. Gibert 968 (K, lectotype).

\section{ACKNOWLEDGEMENTS}

Thanks are due to Olof Ryding, from herbarium C, for the scanning of the two collections included here, and to José Tadeu Weidlich Motta, from herbarium MBM, 


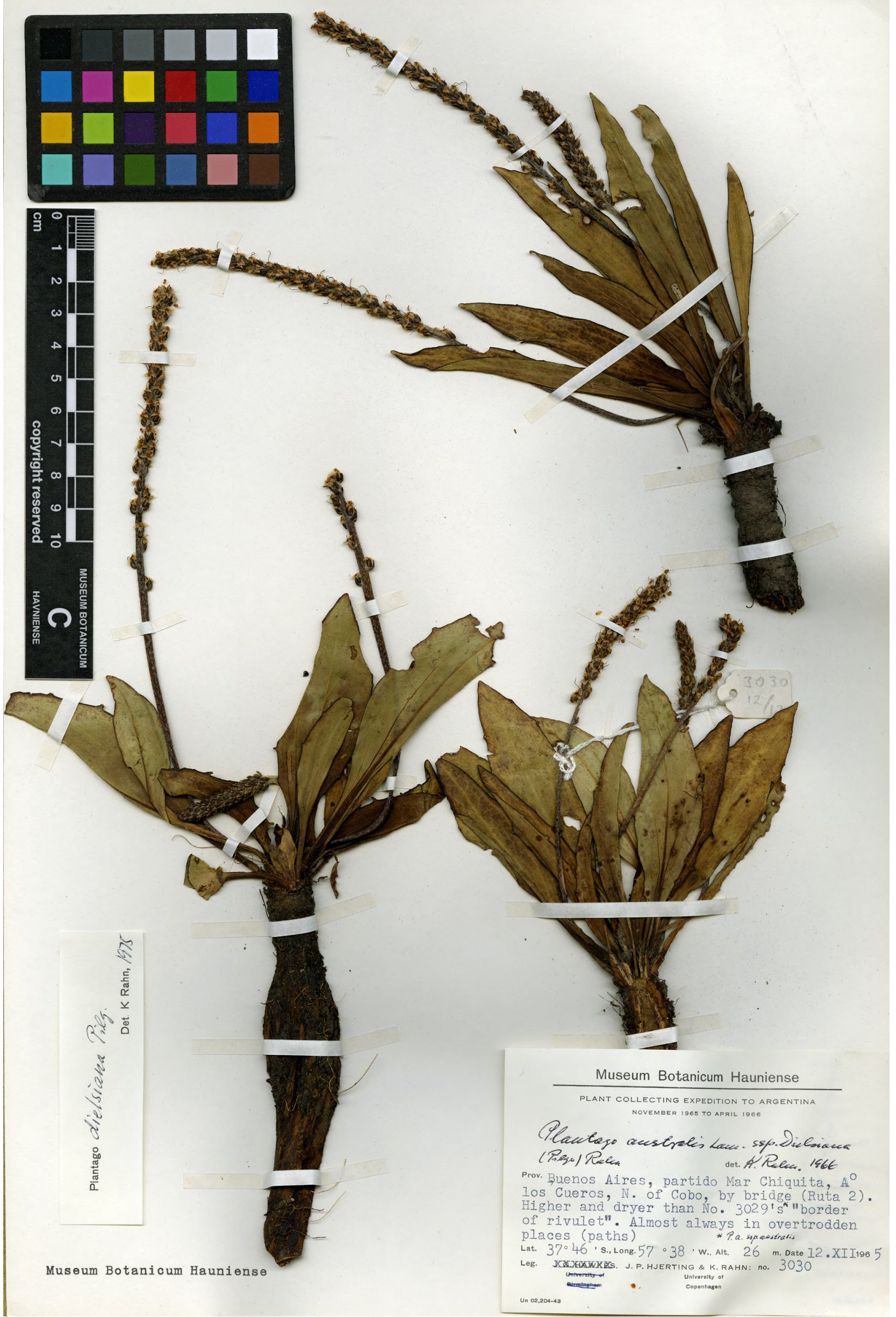

Figure 1. Scanned collection of Plantago dielsiana [J.G. Hawkes et al. 3030, C]. 


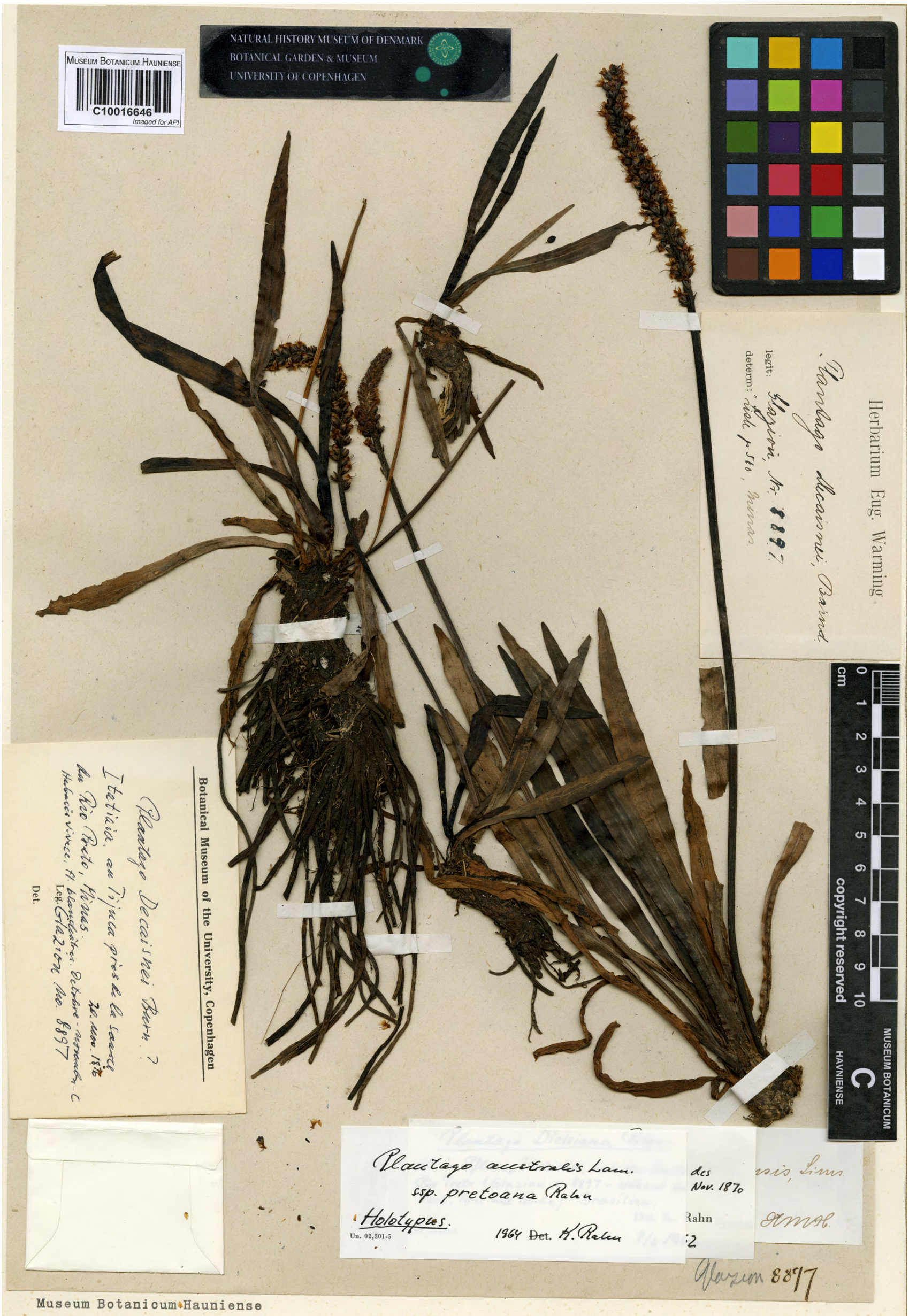

Figure 2. Scanned collection of Plantago australis subsp. pretoana [A.F.M. Glaziou 8897, C, holotype]. 
for the help during fieldwork around Lagoa Dourada, Paraná state, Brazil. GH thanks CAPES (Coordenação de Aperfeiçoamento de Pessoal de Nível Superior) for the scholarship granted through the "Ciência sem Fronteiras" programme.

\section{LITERATURE CITED}

Dunbar-Co, S., A.M. Wieczorek and C.W. Morden. 2008. Molecular phylogeny and adaptive radiation of the endemic Hawaiian Plantago species (Plantaginaceae). American Journal of Botany 95(9): 1177-1188. doi: 10.3732/ajb.0800132

Hassemer, G. and M.C. Baumann. 2014. Plantago corvensis (Plantaginaceae): a new narrowly endemic species from rocky cliffs in southern Brazil. Journal of the Torrey Botanical Society 141(2): 181-185. doi: 10.3159/torrey-d-14-00029.1

Hassemer, G., M.C. Baumann and R. Trevisan. 2014. Plantago rahniana (Plantaginaceae): a narrow endemic, new species from southern Brazil. Systematic Botany 39(2): 637-643. doi: 10.1600/0363644 $14 \times 680960$

Hefler, S.M., W.A. Rodrigues and A.C. Cervi. 2011. O gênero Plantago L. (Plantaginaceae) na região Sul do Brasil. Revista Brasileira de Biociências 9(3): 297-321. http://www.ufrgs.br/seerbio/ojs/ index.php/rbb/article/view/1696

Ishikawa, N., J. Yokoyama and H. Tsukaya. 2009. Molecular evidence of reticulate evolution in the subgenus Plantago (Plantaginaceae). American Journal of Botany 96(9): 1627-1635. doi: 10.3732/ ajb.0800400

IUCN. 2012. IUCN Red List Categories and Criteria. Version 3.1. $2^{\text {nd }}$ ed. Gland: International Union for the Conservation of Nature. $32 \mathrm{pp}$. Accessed at http://jr.iucnredlist.org/documents/redlist_ cats_crit_en.pdf, 1 February 2015.

IUCN. 2014. Guidelines for using the IUCN Red List Categories and Criteria. Version 11. Gland: International Union for the Conservation of Nature. $87 \mathrm{pp}$. Accessed at http://jr.iucnredlist. org/documents/RedListGuidelines.pdf, 1 February 2015.

Kaehler, M. 2014. Plantaginaceae; p. 161, in: M. Kaehler, R. Goldenberg, P.H.L. Evangelista, O.S. Ribas, A.O.S. Vieira and G.G. Hatschbach (eds.). Plantas vasculares do Paraná. Curitiba: Universidade Federal do Paraná.

Martinelli, G. and M.A. Moraes (orgs.). 2013. Livro Vermelho da Flora do Brasil. Rio de Janeiro: Centro Nacional de Conservação da Flora, Jardim Botânico do Rio de Janeiro and Andrea Jakobsson Estúdio. $1100 \mathrm{pp}$

Meudt, H.M. 2011. Amplified fragment length polymorphism data reveal a history of auto-and allopolyploidy in New Zealand endemic species of Plantago (Plantaginaceae): new perspectives on a taxonomically challenging group. International Journal of
Plant Sciences 172(2): 220-237. doi: 10.1086/657657

Meudt, H.M. 2012. A taxonomic revision of native New Zealand Plantago (Plantaginaceae). New Zealand Journal of Botany 50(2): 101-178. doi: 10.1080/0028825x.2012.671179

Mohsenzadeh, S., V. Nazeri and M. Mirtadzadini. 2010. A new species of Plantago (Plantaginaceae) from Iran. Novon 20(3): 307-310. doi: $10.3417 / 2008010$

Pilger, R.K.F. 1928. Die Gattung Plantago in Zentral- und Südamerika. Botanische Jahrbücher für Systematik, Pflanzengeschichte und Pflanzengeographie 62: 1-112.

Pilger, R.K.F. 1937. Plantaginaceae. Das Pflanzenreich 4(269): 1-466.

Rahn, K. 1964. Plantago sect. Novorbis: subspecies et combinationes novae. Botanisk Tidsskrift 6o: 47-57.

Rahn, K. 1974. Plantago section Virginica: a taxonomic revision of a group of American plantains using experimental, taximetric and classical methods. Dansk Botanisk Arkiv 30(2): 1-180.

Rahn, K. 1983. Plantago ser. Brasilienses, a taxonomic revision. Nordic Journal of Botany 3(3): 331-342.

Rahn, K. 1995. Plantaginaceae. Flora Fanerogámica Argentina 269:1-24. http://www.floraargentina.edu.ar/publicaciones/plantaginaceae.pdf

Rahn, K. 1996. A phylogenetic study of the Plantaginaceae. Botanical Journal of the Linnean Society 120: 145-198. doi: 10.1111/j.10958339.1996.tboo484.x

Rønsted, N., M.W. Chase, D.C. Albach and M.A. Bello. 2002. Phylogenetic relationships within Plantago (Plantaginaceae): evidence from nuclear ribosomal ITS and plastid trnL-F sequence data. Botanical Journal of the Linnean Society 139: 323-338. doi: 10.1046/j.1095-8339.2002.00070.x

Segarra, D.V. and J.R.I. Wood. 2011. Plantago pyrophila (Plantaginaceae), a new species from the cerrados of eastern Bolivia. Kew Bulletin 66(3): 471-474. doi: 10.1007/s12225-011-9298-4

Souza, V.C. 2010. Plantaginaceae; pp. 1460-1464, in: R.C. Forzza et al. (orgs.). Catálogo de Plantas e Fungos do Brasil. Vol. 2. Rio de Janeiro: Andrea Jakobsson Estúdio and Jardim Botânico do Rio de Janeiro. Accessed at http://reflora.jbrj.gov.br/downloads/ vol2.pdf, 1 February 2015.

Souza, V.C. and G. Hassemer. 2015. Plantaginaceae; in: Lista de Espécies da Flora do Brasil. Jardim Botânico do Rio de Janeiro. Accessed at http://www.floradobrasil.jbrj.gov.br/jabot/floradobrasil/fb191, 1 February 2015.

Authors' contribution statement: $\mathrm{GH}$ revised the herbarium materials and wrote the text. RT and NR revised the text and funded this study.

\author{
Received: October 2014 \\ Accepted: February 2015 \\ Editorial responsibility: Diogo P. Provete
}

